\title{
RELATIONSHIP OF WORK LOAD AND INTERPERSONAL INTERACTIONS WITH WORK FATIGUE IN INPATIENT NURSES AT DR M YUNUS HOSPITAL, BENGKULU
}

\author{
Rina Aprianti, Susilo Wulan, Elza Wulandari
}

School Of Health Sciences Tri Mandiri Sakti, Bengkulu

\begin{abstract}
ABSTRAK
Background: Work fatigue experienced by nurses can hurt the service provided by the hospital. The workload was difference in the capacity or ability of worker with job demand that must be faced. Interpersonal interaction is a relationship, communication, and interaction with other people. The purpose of this study was to determine relationship between workload and interpersonal interactions with subjective work fatigue in inpatient nurses at dr. M Yunus hospital, Bengkulu, Indonesia.

Subjects and Method: This was a cross sectional conducted at dr. M Yunus Bengkulu from August to September, 2020. A sample of 128 nurses in the inpatient room of Dr. Hospital. M Yunus Bengkulu selected by total sampling. The dependent variable was subjective work fatigue. The independent variables were workload and interpersonal interactions. The instrument used was a questionnaire. The data was analyzed by chi square.

Results: There was a statistically significant relationship between workload (OR=9.31; 95\% $\mathrm{CI}=3.86$ to $22.85 ; \mathrm{p}<0.001)$ and interpersonal interactions $(\mathrm{OR}=7.11 ; 95 \% \mathrm{CI}=3.05$ up to $16.76 ; \mathrm{p}<0.001$ ) with subjective work fatigue.

Conclusion: Workload and interpersonal interactions are factors that can cause subjective work fatigue in the inpatient nurses at RSUD Dr. M Yunus Bengkulu.
\end{abstract}

Keywords: Workload, Interpersonal Interaction, Subjective Work Fatigue.

\section{Correspondance:}

Rina Aprianti. School Of Health Sciences Tri Mandiri Sakti, Bengkulu. Jl. Hibrida Raya No.

3, Sidomulyo Gading Cempaka district, Bengkulu, Indonesia. Email:

rina.aprianti89@gmail.com. Mobile: 081373626277

The $7^{\text {th }}$ International Conference on Public Health

Solo, Indonesia, November 18-19, 2020 | 329

https://doi.org/10.26911/the7thicph.04.14 